\title{
Experiences with the Australian Army Medical Corps at Gallipoli
}

\begin{abstract}
Major John Corbin served as a surgeon with the 1st Australian Casualty Clearing Station (1ACCS) at Gallipoli. The 1ACCS was the most forward unit at Anzac Cove where specialist surgeons, anaesthetists, nurses, radiologists and a dentist were to be found. Between 25 April and 20 December 1915, 37100 men were evacuated through the 1ACCS. Major Corbin went on to serve in France and was promoted to Lieutenant Colonel. He survived the war and died in 1930. This is an edited extract of an article originally published in the MJA on 5 February 1916.
\end{abstract}

$n$ making a few remarks on my experiences since leaving Australia as a member of the Expeditionary Force, I must ask for your tolerance if there is an excess of the first personal pronoun.

It is sufficient to describe the trip on the Kyarra, which carried five hospital units from Australia, as one of great discomfort, lasting six weeks before we arrived at Alexandria.

The No. 1 Australian Stationary Hospital disembarked on the 23rd of January, and entrained for Cairo. On arrival we were sent to Maadi, an English suburb of Cairo, near which the Light Horse camp was situated ... Our life settled down into a dull routine, with the exception of my own, for, on the 10th of February, I developed pleurisy and bronchopneumonia, finally being sent to the No. 1 General Hospital at Heliopolis, where I remained until the 28th [of February], when I rejoined my unit.

The following day, we received orders to pack and prepare to leave Egypt the next day. We entrained on the evening of the 2nd [of March], and embarked on a transport at Alexandria the following morning and ... arrived at the harbour of Mudros on the 6 th.

Owing to the weather, I believe, our starting was postponed until the 24th of April, when we left Mudros at 11 am, steaming out through the lines of transports and battleships, with a piper's band playing, and proceeded due west, and then north to a rendezvous on the other side of Lemnos. We breakfasted at $2 \mathrm{am}$, and found ourselves underway in the most absolute silence, no lights anywhere, except the small red lamp astern of the next transport in front of us. There was a ghostly shape on either flank of a torpedo destroyer.

Everyone was on deck, and as the grey of the coming dawn became less dense, we turned in towards the Gallipoli Peninsula and slowly crept in towards the land. As the light became a little more marked, we could see a transport on either side of us stealing in

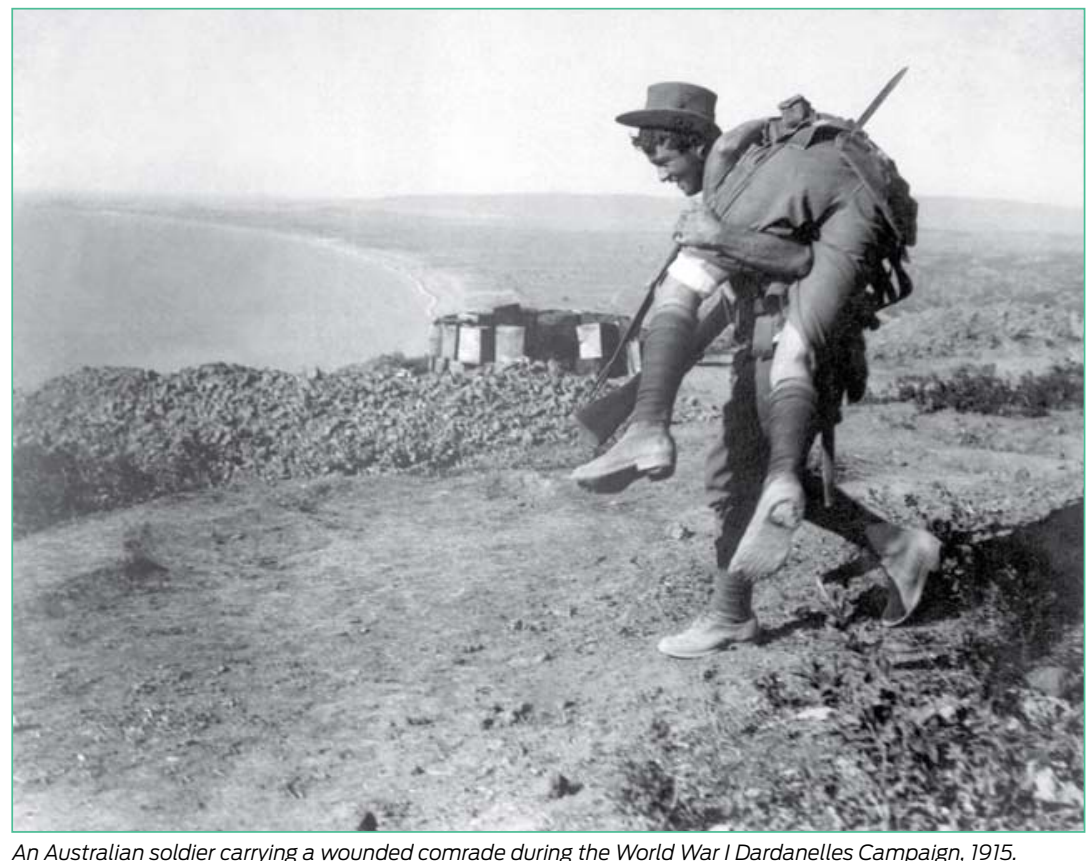

slowly, level with us, and gradually the line of the coast became apparent as a dim outline.

A single shot was heard at 4.30 by my watch. There was silence for a short space, and then the rattle of musketry. Very soon afterwards, guns began firing from the right of the position and the warships began to reply. As the sun rose just before 5 am, everything became clearer, and we could see where our shells were bursting in the vicinity of the Turkish guns, whose flash could be seen clearly each time they fired, and then, later, would come the smoke over the beach, which denoted the bursting of shrapnel.

At 5.30 am we could see the cliffs and recognise their steepness and the difficulties. Our men could be seen climbing up wherever there was foothold and disappearing over the first ridge. At this time, a pinnace came alongside with a man shot through the chest, who died in 5 minutes after getting him on 
board, and another who was shot through the arm. These two made one realise that it was not a pageant for our amusement, but a serious and horrid affair, and that the pretty puffs of smoke, like cotton wool, contained shrapnel bullets, which killed and maimed men. A little later, another boat brought a dead private of the 12th Battalion and seven wounded. These had never landed at all.

We did not get a tow ashore until just after $10 \mathrm{am}$, and this journey, in a crowded boat, towards the beach was one of the most uncomfortable I have ever undertaken ... There were wounded everywhere ... I have never seen anything that looked so like absolute hopeless disorder, and nothing in my life has given me such an impression of human energy as that beach.

Fortunately, we had work to do from the moment of landing, and no room for fear. Nothing removes this hideous feeling of emptiness in the pit of the stomach and strangles out fright like having something you must do and which you can't do without using your mind and concentrating your attention.

During the first 4 days, we were working almost continuously... After the first 24 hours, we tried to get regular relief of one or another, and snatched short periods of sleep, but this merely meant lying down on the beach in our clothes, and covered with a single blanket, we slept, thoroughly exhausted, until roused to work again.

During those first 4 days, 3300 wounded passed through our hands... All urgent operations were done, including necessary amputations, tying of arteries, several belly cases, depressed, compound fractures of skull, bladder cases and big, compound fractures of the thigh. All these necessitated anaesthetics, which were administered in nearly every instance by non-commissioned officers or by privates.

We could not get any wounded off the beach until night, as all boats and tows were needed to bring in supplies and troops. We began to evacuate them at $5 \mathrm{pm}$, and got about 600 off by $8 \mathrm{pm}$. They lay, during the day, all along the beach, for several hundred yards, in what shelter we could devise, much of it inadequate, of course. They were all given surgical care and some food, tea, Bovril, biscuits, etc. Many were hit by shrapnel while lying there, and had to be re-dressed.

During the advance immediately following the landing, the work of the regimental surgeons and stretcher-bearer sections of the Field Ambulances
I have never seen anything that looked so like absolute hopeless disorder ... as that beach was beyond praise. Nothing could exceed their fearless devotion to duty, the way they exposed themselves to risk in order to carry help to the wounded ... and the physical labour of carrying men up and down precipitous ravines, covered in prickly bush and dense undergrowth amazed me.

They dressed hideous wounds efficiently, helped us intelligently to adjust splints to hateful compound fractures, gave chloroform hundreds of times and assisted at operations. All this was done in a quiet, matter-of-fact way, no fainting, no vomiting, just a steady attention to duty and listening to commands and profiting by instruction. Just one more instance of Australian adaptability.

Their courage, too, was fine, for remember, they were under fire more or less all the time. The stretcherbearers of our unit went up the hillside all along the beach and on the piers and never failed in this necessary and very dangerous duty.

Several of our men were put out of action by shrapnel bullets, the shelter-shed for wounded was pierced by a huge explosive shell, which killed a sick man lying on a stretcher, wounded another and so shattered the leg of a member of our unit that it had to be amputated 2 days later on a hospital ship, and he died.

When the fighting on the 5th and the 6th of August took place, and, later, the fighting from the 7 th to the 12 th ... in just over 50 hours roughly 5000 were handled by our station.

I could talk for hours of the dash, heroism and amusing characteristics of the Australian troops, both in action, in trenches and when wounded ... I could tell you many amusing stories of the soldiers and details of Cavanagh Mainwaring, thin as a herring, grey as a badger, loving his work, doing it fearlessly and conscientiously, and loved by his men; of young Fry, doing splendid work... with a permanent cigarette in his funny little holder, quite unchanged by war's alarms; of young Nott, with a fierce, black beard and looking after his wounded in a fearless way. Jermyn and Meikle we saw often on the beach. Young Gordon was greatly admired by the men... and his death greatly felt.

I could not say ill of one man whom I met on the beach at Anzac, fighting men, stretcher-bearers, army service corps, padre men, all have done their bit and done it well, and I am truly proud to have been associated with them. 